\title{
De etnische politieke elite van Nederland: gewoon geworden door ongewoon te zijn?
}

Roos van der Zwan en Tomas Turner-Zwinkels

ABSTRACT: An ethnic political elite in the Netherlands: atypically typical?

This article compares the study and professional backgrounds of ethnic minority and native Dutch MPs in the Netherlands using self-collected data from 2010-2016. We build on previous studies and further develop and test the compensation and similarity model. We expected that ethnic minorities compensate with regard to the duration of their education and the length of their professional and pre-parliamentarian political careers. Furthermore, in line with the similarity model, we expected greater similarities between ethnic minority and Dutch MPs in terms of their educational and professional backgrounds and political experience. The results show more evidence for the similarity model than for the compensation model. We find that ethnic minority MPs have similar educational levels and types of political experience as Dutch MPs, however, contrary to the expectation they do not have more but less years of professional and pre-parliamentarian political experience.

KEYWORDS: ethnic minorities, political representation, the Netherlands, compensation, similarity

\section{Inleiding}

Hoewel de aanwezigheid van etnische minderheden in de Nederlandse Tweede Kamer de afgelopen decennia gestaag groeide, is de groep nog steeds ondervertegenwoordigd. In 2012 had 16,6\% van de Nederlanders een niet-Nederlandse achtergrond (4,7\% westers en $11,9 \%$ niet-westers; CBS, 2016). In datzelfde jaar had $12 \%$ van de Kamerleden een niet-Nederlandse achtergrond, van wie 2,7\% 
westers en 9,3\% niet-westers (van der Zwan, Lubbers \& Eisinga, aanstaande). Verklaringen voor de politieke ondervertegenwoordiging van minderheden worden vooral gezocht in institutionele factoren (Bird, 2005) of groepsmobilisatie en etnische organisaties (Celis et al., 2014; Michon \& Vermeulen, 2013). Een andere verklaring die naar ons inzicht te weinig aandacht heeft gekregen, is dat er bij de werving van kandidaten wordt gezocht naar personen met vergelijkbare of betere kwalificaties dan de selectiecommissie en gevestigde Kamerleden (Black \& Erickson, 2000; Durose et al., 2012; Norris \& Lovenduski, 1995). Personen die niet in dit profiel passen, zullen minder snel op de kandidatenlijst komen, bijvoorbeeld omdat partijen bang zijn stemmen te verliezen (Durose et al., 2012; Norris \& Lovenduski, 1995; Sobolewska, 2013). Wanneer deze veronderstelling klopt, dan zou het resultaat daarvan te zien moeten zijn in de achtergrondkenmerken van Tweede Kamerleden van niet-Nederlandse herkomst. Dat laatste is de focus van deze bijdrage.

Uit onderzoek naar de achtergrondkenmerken van Kamerleden weten we dat de standaard verkozen politicus een blanke, hoogopgeleide, heteroseksuele man van middelbare leeftijd is (Black \& Erickson, 2000; Bovens \& Wille, 2010; Durose et al., 2013; Norris \& Lovenduski, 1995). In hoeverre Kamerleden met een nietNederlandse achtergrond op andere dimensies dan etniciteit hetzelfde patroon laten zien weten we echter niet. Een belangrijke redenen hiervoor is een gebrek aan data. In dit onderzoek gebruiken we daarom een nieuwe, Nederlandse, dataset met gegevens over de etnische achtergrond en gedetailleerde informatie over de studieen beroepskenmerken van Tweede Kamerleden uit de parlementaire cohorten van 2010 en 2012. Hiermee maken we, voor het eerst, een kwantitatieve vergelijking tussen de studie- en beroepskenmerken van Tweede Kamerleden met een Nederlandse en een andere etnische achtergrond.

We vergelijken het studie- en beroepsprofiel van Tweede Kamerleden van Nederlandse en niet-Nederlandse herkomst en proberen deze verschillen tevens te begrijpen. We baseren ons hierbij op het idee dat compensatie- en gelijkheidsdynamieken dergelijke verschillen in achtergrondkenmerken tussen meerderheids- en minderheidsgroepen kunnen verklaren (Black, 2000; Black \& Erickson, 2000). De compensatiedynamiek veronderstelt dat kandidaten behorend tot een minderheidsgroep betere kwalificaties moeten hebben dan die van een meerderheidsgroep, terwijl de gelijkheidsdynamiek impliceert dat ze voornamelijk dezelfde studie- en beroepskenmerken hebben. Er is vooralsnog geen duidelijkheid over welke van deze twee theoretische modellen de voorkeur verdient (Black \& Erickson, 2000). Hoewel eerder beschrijvend onderzoek suggereert dat ondervertegenwoordigde groepen in veel opzichten lijken op standaard verkozenen (Durose et al., 2012; Murray, 2016), zijn in deze studies compensatie-effecten niet onderzocht. Wij onderzoeken daarom de verschillen tussen Kamerleden met een Nederlandse en een niet-Nederlandse achtergrond. De onderzoeksvraag is: 'Wat zijn de belangrijkste 
verschillen tussen de studie- en beroepskenmerken van Kamerleden met een Nederlandse en een andere etnische achtergrond, en welke rol spelen compensatie en gelijkheid in de totstandkoming van deze verschillen?'

Illustratief voor onze interesse is het opleidingsniveau van Kamerleden. In vergelijking met de autochtone Nederlandse bevolking waren niet-westerse minderheden in de periode 2010-2016 lager opgeleid en westerse minderheden hoger opgeleid (CBS, 2017). Onder Kamerleden in het algemeen heeft de meerderheid een universitaire studie afgerond (Bovens \& Wille, 2010; Cotta \& Best, 2007). Er is dus een kloof tussen Tweede Kamerleden en burgers wat betreft het opleidingsniveau maar die is extra groot wanneer het Kamerleden en burgers met een andere etnische achtergrond betreft. Alleen het beschrijven van dergelijke verschillen is niet genoeg. Om barrières voor minderheden in de politiek op te heffen, is meer begrip nodig over de mechanismes die tot deze ongelijkheid leiden.

Behalve een theoretische bijdrage levert dit onderzoek daarmee ook een bijdrage aan het maatschappelijke debat. Het geeft nieuwe inzichten in de descriptieve vertegenwoordiging in Nederland en in de kloof tussen politici en burgers (Bovens \& Wille, 2010; Cotta \& Best, 2007). Als Tweede Kamerleden van niet-Nederlandse herkomst sterk lijken op de autochtone Nederlandse politieke elite, dan kan de kloof tussen etnische minderheden in de samenleving en Tweede Kamerleden daarom immers nog groter zijn dan tussen autochtone Nederlandse burgers en Tweede Kamerleden. Verschillen in achtergrondkenmerken tussen burgers en politici hoeven niet problematisch te zijn, zolang de belangen van verschillende groepen burgers maar behartigd worden. De specifieke kennis en ervaring van Kamerleden uit ondervertegenwoordigde groepen kan echter leiden tot andere agendapunten, inzichten en beleid (Phillips, 1995; Pitkin, 1967). Minderheden van niet-westerse afkomst behoren ook relatief vaak tot een andere ondervertegenwoordigde groep: de lagere sociaaleconomische klasse (Bovens \& Wille, 2010; Cotta \& best, 2007; van Tubergen, 2006). ${ }^{1}$ Als blijkt dat voor etnische minderheden compensatie en/ of gelijkheid nodig zijn om een plek in de Kamer de bemachtigen, dan hebben zij nog minder overeenkomsten met burgers met dezelfde etnische achtergrond. Zij vormen dan mogelijk een etnische politieke elite, wier kennis en ervaring nog maar matig overeenkomt met hun potentiële achterban.

In wat volgt gaan we eerst in op de Nederlandse context. Vervolgens bespreken we ons theoretische kader. De nadruk hier ligt op het selectieproces van Kamerleden en de mogelijke rol die compensatie en gelijkheid hierin spelen. Na een korte omschrijving van de data en de methoden bestuderen we vervolgens op kwantitatieve wijze de verschillen in studie- en beroepskenmerken tussen politici met een Nederlandse en een niet-Nederlandse achtergrond. In de discussie en de conclusie komen we terug op compensatie en gelijkheid en beschouwen we welke van deze twee dynamieken het meest dominant lijkt in Nederland. 


\section{De politieke integratie van etnische minderheden in Nederland}

Het jaar 1986 was belangrijk voor de politieke integratie van minderheden in Nederland: sinds dat jaar mogen migranten stemmen voor de lokale verkiezingen; ook werd toen het eerste Tweede Kamerlid met een niet-westerse achtergrond verkozen. Dat was John Lilipaly, een onderwijzer van Molukse afkomst (Rath, 1990; Tillie, 1998). Van de belangrijkste niet-westerse migrantengroepen in Nederland (uit Turkije, Marokko, Suriname en de Antillen), blijken Nederlanders met een Turkse achtergrond het meest actief (Fennema \& Tillie, 1999; Michon \& Vermeulen, 2013). De Partij van de Arbeid (PvdA) speelde vanaf het begin een belangrijke rol voor migranten (Ensel, 2003). Zowel in hun partijprogramma als vanuit de partij zelf ondersteunen zij migranten, zoals met een migrantennetwerk (Ensel, 2003). Het is tevens een populaire partij onder etnische stemmers (Fennema \& Tillie, 1999; Tillie, 1998; Michon \& Vermeulen, 2013) en in de partij zijn veel etnische minderheden actief (Rath, 1990).

We weten dus dat migranten politiek actief zijn in Nederland, maar verklarend onderzoek naar hun politieke vertegenwoordiging is schaars. Studies die kijken naar de selectie laten zien dat etnische organisaties, migrantennetwerken binnen partijen en partijelites een rol spelen in de mate van vertegenwoordiging (Michon \& Vermeulen, 2013; Mügge, 2016). Uit meer beschrijvend onderzoek blijkt ook dat het aantal Tweede Kamerleden met een niet-Nederlandse achtergrond in Nederland langzaam is toegenomen (Mügge, 2016). Of Kamerleden met een niet-Nederlandse achtergrond ook de culturele en religieuze belangen van de eigen etnische groep behartigen is nog een punt van discussie (Aydemir \& Vliegenthart, 2016). Andere achtergrondkenmerken van deze groep, zoals de relatieve oververtegenwoordiging van vrouwen (Celis et al., 2014; Mügge, 2016) of een verschil in opleidingsniveau en studieachtergrond, spelen hier waarschijnlijk een rol in.

\section{Selectie, compensatie en gelijkheid}

\subsection{Selectie}

Alvorens wij compensatie en gelijkheid verder uitwerken is het belangrijk om kort stil te staan bij het selectieproces in brede zin. Voordat politici daadwerkelijk tot Kamerlid verkozen worden, hebben zij immers al een uitgebreid selectieproces doorlopen. Dat begint met het aanbod; niet alle burgers zijn lid van een politieke partij en van diegenen die dat wel zijn, kunnen we aannemen dat zij in ieder geval politiek geïnteresseerd zijn. Binnen partijen kunnen partijleden zich kandidaat 
stellen of als kandidaat voorgedragen worden voor de kandidatenlijst (Lucardie \& Voerman, 2004). Vervolgens stellen selectiecommissies de kandidatenlijst van een partij samen en bepalen daarmee op wie kiezers kunnen stemmen. Deze commissies bepalen ook de lijstvolgorde waarbij rekening wordt gehouden met de veilige lijstposities, ofwel het aantal zetels dat een partij verwacht te winnen. Omdat de kandidaten die op de hoogste lijstposities worden geplaatst ook de grootste kans hebben op een zetel, hebben selectiecommissies een bijzonder grote invloed op wie er in de Tweede Kamer komt (Scarrow et al., 2000). ${ }^{2}$ In het laatste deel van het selectieproces bepalen de kiezers alleen nog hoeveel zetels elke partij krijgt. Omdat partijen een grote rol spelen in de politieke vertegenwoordiging van minderheidsgroepen (Norris \& Lovenduski, 2005) focussen wij redelijkerwijs op de selectie van kandidaten door selectiecommissies.

Ons theoretische startpunt is ten eerste dat partijen risicomijdend zijn en ten tweede dat ze zo veel mogelijk stemmen willen behalen. Partijen zullen daarom kandidaten selecteren van wie ze denken dat ze succesvol zijn en kiezers aantrekken (Norris \& Lovenduski, 1995). Een kandidaat uit een minderheidsgroep selecteren kan een strategie zijn om nieuwe kiezers aan te trekken, maar kan tegelijkertijd ook kiezers afstoten die liever geen etnische minderheden in de politiek zien (Norris \& Lovenduski, 1995; Sobolewska, 2013). Selectiecommissies balanceren logischerwijs tussen deze twee overwegingen en kiezen daarom kandidaten die 'acceptabel anders' zijn. Minderheidsgroepen worden dan wel vertegenwoordigd maar de kandidaten zijn niet zo anders dat de partij denkt dat het haar stemmen zal kosten (Durose et al., 2012).

Dat roept echter de vraag op wat 'acceptabel anders' precies is. Informatie over daadwerkelijke strategieën en ideeën daarover van leden van de selectiecommissies is er nauwelijks. Het is lastig te achterhalen hoe het eraan toegaat tijdens de selectieprocedure. ${ }^{3}$ We kunnen echter wel kijken naar de uitkomst van die procedure en bestuderen wie de uiteindelijke Kamerleden zijn. Daarbij zijn specifieke uitkomsten die wijzen op compensatie- of gelijkheidsdynamieken van belang.

\subsection{Compensatie en gelijkheid}

Zowel compensatie als gelijkheid kunnen verklaren welke leden van minderheidsgroepen politiek succesvol zijn. Het compensatiemodel stelt dat om politiek succesvol te zijn, mensen uit minderheidsgroepen een sterker profiel moeten hebben dan standaard verkozenen (Black \& Erickson, 2000). Zij stellen dat negatieve associaties en vooroordelen over minderheidsgroepen een rol spelen in het wervingsproces. Hierdoor kunnen alleen de kandidaten met buitengewoon goede competenties hun 'anders zijn' compenseren (Black, 2000). Volgens het gelijkheidsmodel zullen personen die op een van de kenmerken van de standaard verkozene afwij- 
ken en politiek succesvol willen worden, op overige kenmerken meer in het profiel moeten passen (Black, 2000; Black \& Erickson, 2000). Dit model gaat daarbij niet zozeer uit van de selectiemethodes van selectiecommissies maar van de achtergrondmerken, zoals opleidings- en beroepsachtergrond, van potentiële Kamerleden. Ze stellen dat alleen de leden uit de minderheidsgroep die lijken op de meerderheidsgroep genoeg kans hebben om Kamerlid te worden.

De literatuur zet deze modellen tegenover elkaar, waarbij wordt aangenomen dat of het ene model of het andere model het meest relevant is. In een onderzoek onder vrouwelijke politieke kandidaten in Canada laten Black en Erickson (2000) bewijs zien voor zowel het compensatiemodel als voor het gelijkheidsmodel. In hun onderzoek blijkt voor bepaalde aspecten, zoals preparlementaire politieke ervaring, het compensatiemodel op te gaan terwijl voor andere aspecten, zoals opleidingsniveau, het gelijkheidsmodel meer van toepassing is.

Wij verwachten echter dat zowel compensatie- als gelijkheidsdynamieken voorkomen en dat beide dus relevant zijn. Hierbij putten we uit literatuur over discriminatie op de arbeidsmarkt die stelt dat discriminatie niet altijd voortkomt uit racisme, maar als een rationele keuze beschouwd kan worden (Arrow, 1971; Phelps, 1972). Een werkgever moet met beperkte informatie een inschatting maken of de potentiële werknemer voldoende gekwalificeerd is voor de baan. De kosten om uitgebreide informatie over potentiële werknemers te verkrijgen zijn vaak hoog. Er wordt verondersteld dat werkgevers daarom indirecte aanwijzingen gebruiken, bijvoorbeeld een niet-Nederlandse naam op een $\mathrm{cv}$, om een inschatting te maken van individuele potentiële werknemers. Als duidelijk is dat het gaat om iemand met een andere etnische achtergrond, kunnen subjectieve overtuigingen over die etnische groep van invloed zijn op de keuzes van de werkgever. Als een werkgever het idee heeft dat etnische minderheden in het algemeen minder gekwalificeerd zijn of minder hard werken, wordt wellicht de voorkeur gegeven aan een autochtone Nederlandse kandidaat. Door beperkte informatie over sollicitanten is het dus mogelijk dat niet de meest gekwalificeerde kandidaat wordt aangenomen (Zschirnt \& Didier, 2016).

Selectiecommissies zijn in het geval van politieke selectie de werkgever; ze bepalen welke kandidaten het meest geschikt zijn om op de kandidatenlijst te worden geplaatst. Een belangrijke bijkomstigheid in het politieke domein is hierbij dat diversiteit voor politieke partijen steeds belangrijker wordt. Hoewel dat per partij verschilt, zullen veel commissies dus een prikkel hebben om ten minste enkele kandidaten met een andere etnische achtergrond te selecteren. Kortom, het is voor politieke partijen nauwelijks een optie om geen etnische minderheden te selecteren voor de kandidatenlijst. Dat verlegt de aandacht van het aantal minderheden in de Tweede Kamer, naar wie er geselecteerd wordt.

Politieke selectiecommissies moeten dus met beperkte informatie een inschatting maken van de kwalificaties van de potentiële kandidaat. Selectiecommissies 
zullen de kandidaten kiezen van wie ze denken dat ze het meest succesvol zullen zijn. Dat zijn kandidaten die niet alleen populair zijn bij de kiezer maar van wie ze ook verwachten goed te presteren in de Tweede Kamer. Voor kandidaten met een andere etnische achtergrond verwachten we hierbij dat, door beperkte informatie, subjectieve overtuigingen over etnische minderheden als groep op het individu kunnen worden geprojecteerd. In de politieke context kunnen dat bijvoorbeeld aannames over politieke en bestuurlijke kennis van Nederland zijn, maar ook aannames over de populariteit van de kandidaat bij de kiezers. Hieruit volgt dat er wel kandidaten met een andere etnische achtergrond worden aangenomen, maar in overeenstemming met het compensatiemodel zou een kandidaat die, omdat zijn/haar etniciteit niet binnen het standaard profiel valt, daarvoor moeten compenseren met sterkere studie- en beroepskenmerken. We verwachten dus dat wanneer selectiecommissies kiezen voor een kandidaat met een niet-Nederlandse achtergrond, de kwalificaties van deze persoon nog beter zijn dan die van het standaard Tweede Kamerlid. De belangrijkste dimensies waarop selectiecommissies kandidaten met elkaar kunnen vergelijken zijn hun opleiding (Bovens \& Wille, 2010), werkervaring (Fennema, 2003) en politieke achtergrond (Keane \& Merlo, 2007). Hieruit volgt de volgende verwachting: bij binnenkomst in de Tweede Kamer zijn Kamerleden met een niet-Nederlandse achtergrond vaker hoger opgeleid (H1a), hebben ze meer werkervaring (H1b) en meer politieke ervaring (H1c) dan het standaard Kamerlid.

Het is niet altijd gemakkelijk om te bepalen wat betere kwalificaties zijn. Gelukkig is dat waar het compensatiemodel en het gelijkheidsmodel elkaar aanvullen. Kandidaten kunnen wel hoger opgeleid zijn dan een standaard Kamerlid (compensatie), maar het is echter lastig te compenseren op studieachtergrond. Bijvoorbeeld, als de meeste Tweede Kamerleden een sociale studie hebben gedaan, wat is dan de betere studie? Daarom verwachten we dat bij het 'type' studie- of beroepskenmerk (opleidingsachtergrond, beroepsachtergrond en type politieke ervaring) niet compensatie maar gelijkheid de dominante dynamiek is. De geschiktheid van een kandidaat is voor een selectiecommissie beter in te schatten als deze kandidaat lijkt op de standaard verkozene. Als een commissie bijvoorbeeld ervaring heeft met Kamerleden die een sociale studie hebben gedaan, uit de publieke sector komen en vooral in de lokale politiek actief waren, levert dat extra informatie die ze kunnen gebruiken om beter in te schatten hoe kandidaten met een vergelijkbare achtergrond in de Kamer zullen presteren. Vooral als een kandidaat door zijn etnische achtergrond afwijkt van het standaard profiel en niet kan compenseren, zal het een veilige keuze zijn om voor kandidaten te gaan die wat betreft andere kenmerken bekend zijn. Onze tweede hypothese is daarom dat: Kamerleden met een niet-Nederlandse achtergrond bij binnenkomst in de Tweede Kamer vaker dezelfde studieachtergrond (H2a), dezelfde beroepsachtergrond (H2b) en hetzelfde type politieke ervaring $(\mathrm{H} 2 \mathrm{c})$ hebben als het standaard Kamerlid. 
Op basis van het compensatie- en gelijkheidsmodel verwachten we dus dat 'acceptabel anders' in de praktijk verwijst naar zowel betere kwalificaties, als sterker vergelijkbare kwalificaties. Het is bovendien waarschijnlijk dat compensatie en gelijkheid zich tegelijkertijd voordoen. Als dat het geval is, dan zal ongelijkheid (een ongewoon type ervaring) gewoonlijk gecompenseerd moeten worden met meer ervaring. Om te onderzoeken of dat klopt, toetsen wij of Kamerleden van niet-Nederlandse herkomst die wat betreft hun type ervaring - oftewel, studieachtergrond, beroepsachtergrond en type politieke ervaring - afwijken van de norm in de Tweede Kamer hiervoor moeten compenseren met de duur van hun ervaring in deze domeinen. Bijvoorbeeld, als de meeste Kamerleden uit de publieke sector komen dat een Kamerlid van niet-Nederlandse herkomst die uit de private sector komt, hiervoor moet compenseren met meer professionele werkervaring. We testen daarom tevens de derde en laatste hypothese dat: Kamerleden met een nietNederlandse achtergrond die niet de meest voorkomende studieachtergrond (H3a), beroepsachtergrond (H3b) of politieke ervaring hebben (H3c) hiervoor compenseren met respectievelijk een hoger opleidingsniveau en meer professionele en politieke ervaring. Als we in onze resultaten empirisch steun voor deze hypothese vinden, dan is dat een indicatie dat de compensatie en gelijkheid niet elkaars theoretische tegenpolen hoeven te zijn, maar elkaar ook kunnen aanvullen. Dat zou een verklaring bieden voor de wisselende resultaten uit eerder onderzoek.

\section{Methode}

\subsection{Data}

Voor de empirische analyse in dit artikel maken we gebruik van een recent samengestelde dataset. Deze nieuwe dataset (Turner-Zwinkels, aanstaande) bevat gedetailleerde carrièredata van alle Tweede Kamerleden sinds 1945. Ten grondslag aan deze dataset ligt het online archief van het parlementair documentatiecentrum. Informatie wat betreft de etnische achtergrond van Kamerleden is afkomstig uit een dataset van van der Zwan (Zie: van der Zwan, Lubbers \& Eisinga, aanstaande). Deze dataset bevat informatie over alle Kamerleden die bij de verkiezingen van 2010 of 2012 een zetel behaalden in de Tweede Kamer. Omdat betrouwbare informatie over de etnische achtergrond van Kamerleden in eerdere parlementen ontbreekt, gebruiken we voor onze analyses de populatie met daarin alle $(\mathrm{N}=217)$ Tweede Kamerleden die in de kabinetsperiode van 2010 tot 2012 (al dan niet tijdelijk) zitting hebben gehad in de Tweede Kamer. Object van studie is het profiel (etnische achtergrond, politieke en professionele achtergrond) van politici op het moment dat zij voor het eerst de Kamer binnenkomen. 


\subsection{Variabelen}

\subsubsection{Etnische achtergrond}

We meten etnische achtergrond op basis van het land van herkomst. Wij volgen hierbij de definitie van het CBS en beschouwen een Tweede Kamerlid als hebbende een niet-Nederlandse achtergrond wanneer die zelf en/of de ouders niet in Nederland zijn geboren. Dat omvat de eerste en de tweede generatie en alle Nederlanders met een andere etnische achtergrond, dus zowel westerse als niet-westerse Kamerleden. ${ }^{4}$ Een focus op niet-westerse achtergrond verandert de bevindingen niet (analyse beschikbaar op verzoek). In totaal hebben 28 Kamerleden in onze data $(12,90 \%)$ een niet-Nederlandse achtergrond. Hiervan zijn er $5(2,30 \%)$ met een westerse achtergrond en $23(10,60 \%)$ met een niet-westerse achtergrond.

\subsubsection{Opleidingsniveau}

Heeft een Kamerlid ( $\mathrm{ja}=1$, nee $=0$ ) aan een (binnenlandse of buitenlandse) universiteit gestudeerd voor binnenkomst in de Kamer en een diploma behaald. Dat is het geval voor 76,50\% van alle Kamerleden in de data.

\subsubsection{Hoeveelheid professionele werkervaring}

Het aantal jaren werkervaring in betaalde beroepen van een Kamerlid bij binnenkomst in de Kamer $(M=13,92, S D=9,79)$. Dat omvat zowel parttime- als fulltimebanen op basis van het volledige $\mathrm{cv}$.

\subsubsection{Hoeveelheid politieke werkervaring}

Het aantal jaren politieke ervaring van een Kamerlid bij binnenkomst in de Kamer $(\mathrm{M}=8,39, \mathrm{SD}=10,93)$. Dat omvat zowel electoraal verkozen (bv. lid gemeenteraad, Statenlid) als niet-electoraal verkozen politieke functies (bv. partijbestuurder) en betaalde en niet-betaalde functies, gebaseerd op het complete cv.

\subsubsection{Studieachtergrond}

Vakgebied van de (universitaire) studie (gebaseerd op de internationale ISCED13-F 'Field of Study'-standaard). We coderen het hoogst behaalde niveau. Er zijn tien 
categorieën: 0 Algemene kwalificaties, ${ }^{5} 1$ Lerarenopleiding, 2 Geesteswetenschappen, 3 Sociaal(wetenschappelijke) opleiding, 4 Bestuurskunde/rechten, 5 Natuurkunde/wiskunde/biologie/statistiek, 6 Informatietechnologie, 7 Techniek \& Bouwkunde, 8 Landbouwwetenschappen, 9 Levenswetenschappen, 10 Dienstgerichte opleidingen.

\subsubsection{Beroepsachtergrond}

De sector waarin een Kamerlid primair actief was voor binnenkomst in de Tweede Kamer. Een klein aantal observaties maakt een simpele classificatie van preparlementaire carrières hier analytisch noodzakelijk. De gekozen indeling komt voort uit een gedetailleerde 'sequentieanalyse' van de complete beroepsachtergrond van Tweede Kamerleden (Turner-Zwinkels \& Mills, aanstaande). Op basis van deze analyse richten wij ons op de 1) de journalistiek, 2) militaire achtergrond, 3) private sector, 4) publieke sector, 5) vakbondsachtergrond. Voorts is er een restcategorie (6) van Kamerleden die niet consistent in een van deze sectoren gewerkt hebben. Een voorbeeld hiervan is bijvoorbeeld André Bosman, die voordat hij de Kamer in kwam af en aan zowel als commerciële als als militaire piloot werkte.

\subsubsection{Type politieke ervaring}

De politieke arena waarin een Kamerlid primair actief was voor binnenkomst in de Kamer. Dat omvat een onderscheid tussen 1) geen politieke ervaring, 2) lokaal, 3) lokaal en regionaal, 4) nationaal (Eerste Kamer en ondersteunende posities in Tweede Kamer), 5) overige (bv. Europees) en 6) regionaal. Gemeten over de gehele preparlementaire carrière. Posities in het buitenland worden ook meegenomen.

\subsubsection{Controlevariabelen}

Er wordt gecontroleerd voor geslacht (man ('m') of vrouw ('v')) en leeftijd (in jaren).

\subsection{Analytische strategie}

In de kwantitatieve analyse die volgt onderzoeken we verschillen in de studie- en beroepskenmerken van Tweede Kamerleden van Nederlandse en niet-Nederlandse herkomst. Om te beoordelen of de Nederlandse situatie in overeenstemming is met 
de geformuleerde hypothesen gebruiken we zowel beschrijvende als verklarende statistiek. We gebruiken noodgedwongen modellen met weinig variabelen omdat de hoeveelheid Kamerleden met een niet-Nederlandse achtergrond statistisch gezien klein is.

In het eerste deel van de analyse ligt de focus op de compensatiedynamiek (H1); hier vergelijken we de hoeveelheid ervaring van Kamerleden met een niet-Nederlandse achtergrond met die van autochtone Nederlandse Kamerleden. Hiervoor gebruiken we kruistabellen, box-plots en een aantal eenvoudige multivariate regressiemodellen. De afhankelijke variabele in deze analyses is de hoeveelheid politieke en professionele ervaring en het opleidingsniveau. De onafhankelijke variabele is de etnische achtergrond van Kamerleden. Wat betreft het opleidingsniveau moet alvast opgemerkt worden dat de meerderheid van de Kamerleden een universitaire studie heeft gedaan.

In het tweede deel van de analyse, waar de gelijkheidsdynamiek (H2) centraal staat, volgen we steeds twee stappen. In de eerste stap stellen we vast wat de meest voorkomende achtergrond is van Tweede Kamerleden (de 'norm'), oftewel: de studie-, beroeps- of politieke achtergrond die de meeste Kamerleden in de Tweede Kamer hebben. Meer technisch gedefinieerd: we stellen vast welke minimale set aan categorieën samen meer dan $50 \%$ van de gehele onderzoekspopulatie dekt. ${ }^{6}$ Bijvoorbeeld, als $60 \%$ van de Kamerleden uit de private sector komt dan is dat de 'norm'. De norm kan echter ook een combinatie van achtergronden omvatten, als $35 \%$ van de Kamerleden bijvoorbeeld een bedrijfskunde achtergrond heeft en $25 \%$ heeft rechten gestudeerd dan beschouwen we het als de norm om deze twee studies gedaan te hebben. We testen de robuustheid van onze resultaten met alternatieve specificaties van de norm. Omdat het merendeel van de Kamerleden een Nederlandse achtergrond heeft, definieert deze groep de norm. Analytisch is dat geen probleem. Onze hypothese gaat immers over de mate waarin Kamerleden met een niet-Nederlandse achtergrond aan deze norm voldoen.

In de tweede stap vergelijken we vervolgens het percentage Kamerleden van Nederlandse en niet-Nederlandse herkomst dat aan deze norm voldoet. Hiervoor gebruiken we kruistabellen en een aantal eenvoudige multivariate (logistische) regressiemodellen. Alle dimensies van (on)gelijkheid betreffen categorische variabelen. De afhankelijke variabele in deze analyses is daarom simpelweg het voldoen aan de norm ( $\mathrm{ja}=1$, nee $=0$ ). De onafhankelijke variabele is de etnische achtergrond van Kamerleden. In het derde en laatste deel van de analyses bekijken we vervolgens het samenspel tussen deze twee dynamieken (H3). Om dat te testen voegen we een interactie-effect tussen norm (de afhankelijke variabele uit het eerste deel van de analyse) en etniciteit toe aan de regressiemodellen uit stap 2. Als H3, 'de samenspelhypothese' klopt, dan zal het geschatte effect van deze interactie term positief zijn. In de analyses controleren we voor leeftijd en geslacht. In bijlage 1 presenteren we descriptieve statistieken van de individuele variabelen. 


\section{Resultaten}

\subsection{Hoeveelheid ervaring: compensatie?}

We onderzoeken eerst of er sprake is van een compensatiedynamiek. Onze theoretische verwachting is dat Tweede Kamerleden met een niet-Nederlandse achtergrond meer ervaring hebben bij binnenkomst in de Kamer. We verwachten dat specifiek te zien wat betreft het aantal jaren professionele en politieke werkervaring en mogelijk ook qua opleidingsniveau. De resultaten hierna geven verrassend genoeg geen aanleiding om te geloven dat compensatie plaatsvindt.

\subsubsection{Opleidingsniveau}

De descriptieve resultaten in tabel 1 en de logistische regressieanalyse in tabel 2 laten zien dat er geen (meetbaar) verschil is in het percentage Kamerleden met een niet-Nederlandse en een Nederlandse achtergrond met een universitaire opleiding. We vinden hier geen bevestiging voor hypothese 1a. Wij schrijven dat toe aan een plafondeffect. Bijna alle Kamerleden zijn zeer hoog opgeleid; het is dus lastig om daarmee te compenseren.

TABEL 1. Percentage universitair opgeleiden (kolompercentages).

\begin{tabular}{cccc}
\hline \hline & Iedereen, N=217 & Nederlands, N=189 & niet-Nederlands, N=28 \\
\hline Geen univ. opleiding & 24 & 23 & 25 \\
Universitaire opleiding & 76 & 77 & 75 \\
\hline
\end{tabular}

\subsubsection{Jaren professionele werkervaring}

Wat betreft het aantal jaren professionele werkervaring ( $\mathrm{H} 1 \mathrm{~b})$, lijken de beschrijvende (figuur 1) en de verklarende (tabel 6) resultaten te wijzen op een effect in onverwachte richting. We zien in tabel 6 dat het gemiddelde autochtone Nederlandse Kamerlid ongeveer 14,93 [13,23 - 16,64] jaar professionele werkervaring heeft. Het gemiddelde Kamerlid van niet-Nederlandse herkomst heeft daarentegen ongeveer 12,25 [8,43 - 16,06] jaar professionele ervaring. Dat is minder, niet méér, zoals $\mathrm{H} 1$ stelt. Ook deze resultaten ondersteunen het idee dat Kamerleden met een niet-Nederlandse herkomst moeten compenseren dus niet. 
TABEL 2. Geschatte kans op een universitaire opleiding.

\begin{tabular}{lc}
\hline \hline & Afhankelijke variabele: \\
\cline { 2 - 2 } Niet-Nederlands & Universitair opgeleid \\
& -0.114 \\
Geslacht:vrouw & $0.477)$ \\
& 0.169 \\
Leeftijd bij binnenkomst & $(0.335)$ \\
& -0.001 \\
Intercept & $(0.019)$ \\
& 1.174 \\
\hline $\mathrm{N}$ & $(0.825)$ \\
Log Likelihood & 217 \\
Akaike Inf. Crit. & -118.172 \\
\hline \hline Noot 1: & 244.344 \\
Noot 2: & ${ }^{*} \mathrm{p}<0.1 ; * \mathrm{p}<0.05 ; * * * \mathrm{p}<0.01$ \\
& Standaardfout tussen haakjes
\end{tabular}

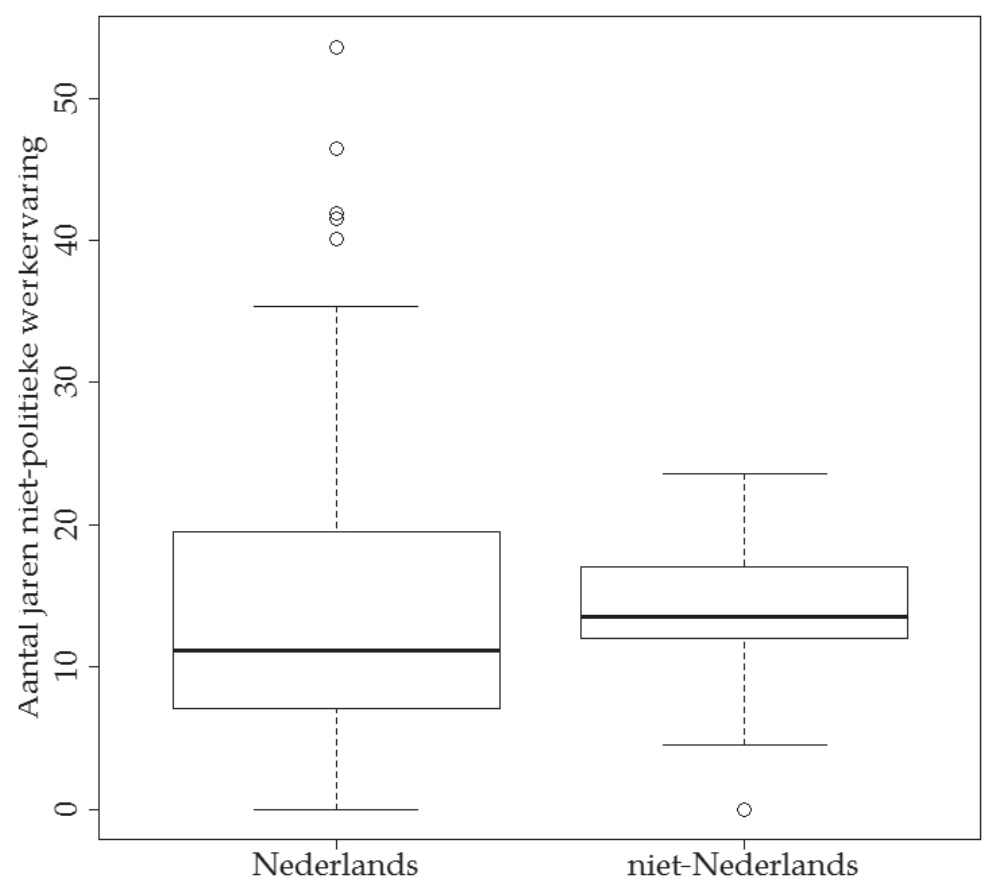

FIGUUR 1. Jaren professionele werkervaring. 


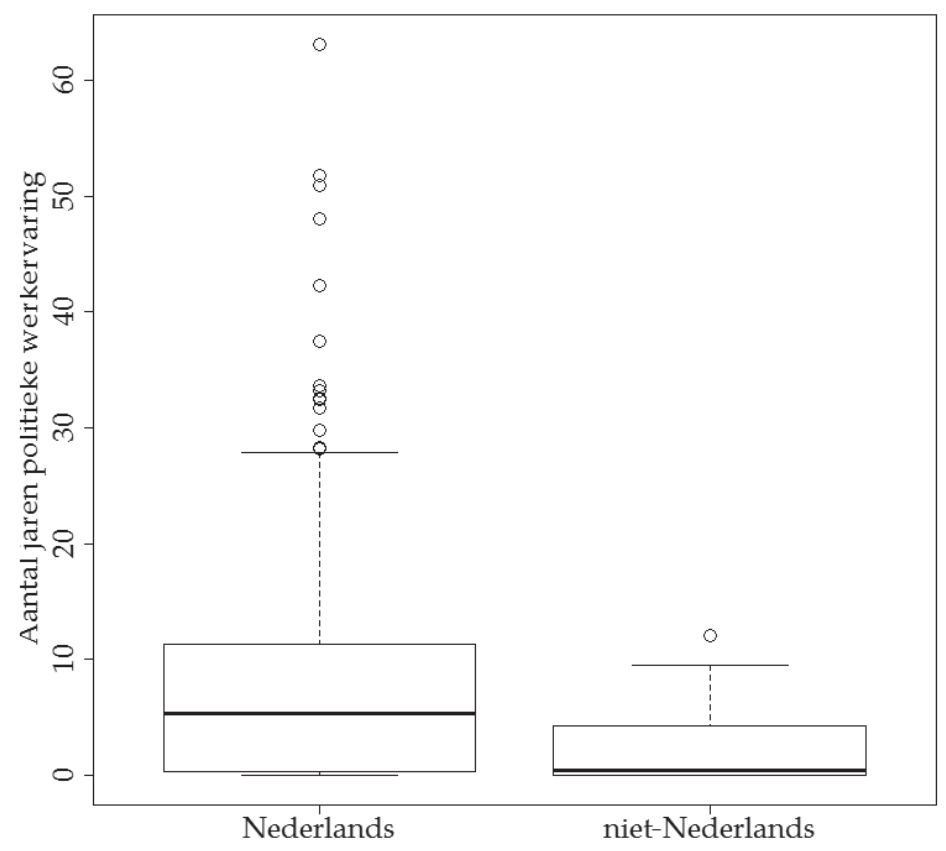

FIGUUR 2. Jaren politieke werkervaring.

\subsubsection{Jaren politieke werkervaring}

Ook wat betreft het aantal jaren politieke werkervaring (H1c) vinden we een onverwacht negatief effect. Opnieuw zien we dat (figuur 2 \& tabel 7) Kamerleden met een niet-Nederlandse herkomst aanzienlijk, en in dit geval ook significant, minder politieke ervaring hebben bij binnenkomst in de Kamer. Waar het gemiddelde (mannelijke) autochtone Kamerlid ongeveer 10,15 [8,27 - 12,02] jaar politieke ervaring heeft, is dat slechts 4,88 [0,67 - 9,08] voor Kamerleden van nietNederlandse herkomst.

Alles bij elkaar genomen vinden we dus weinig steun voor het idee dat Kamerleden van niet-Nederlandse herkomst meer politieke ervaring moeten hebben (H1c). De resultaten wijzen zelfs richting een effect in tegenovergestelde richting.

\subsection{Type ervaring: gelijkheid?}

We onderzoeken vervolgens hypothese 2, de gelijkheidsdynamiek. Hiervoor kijken we naar het type ervaring. Een eerste blik op de resultaten laat zien dat het gemiddelde Tweede Kamerlid in de periode 2010-2016 een hoogopgeleide Neder- 
landse man van 41 was, met een sociaalwetenschappelijke, bestuurskunde- of rechtenopleiding. Hij werkte meestal in de private of publieke sector en deed voor binnenkomst in de Tweede Kamer vooral ervaring op in de lokale politiek. Als een gelijkheidsdynamiek zich voordoet dan zou dit profiel, los van het Nederlanderschap, het sterke dominante profiel moeten zijn onder Kamerleden met een niet-Nederlandse achtergrond. De tabellen 3, 4 en 5 laten zien in hoeverre dat klopt.

\subsubsection{Studieachtergrond}

TABEL 3. Studieachtergrond (kolompercentages).

\begin{tabular}{cccc}
\hline \hline & Iedereen, $\mathrm{N}=\mathbf{2 1 7}$ & Nederlands, $\mathrm{N}=189$ & niet-Nederlands, $\mathrm{N}=\mathbf{2 8}$ \\
\hline 0 Algemene kwalificaties & 20 & 21 & 14 \\
1 Lerarenopleiding & 0 & 0 & 0 \\
2 Geesteswetenschappen & 10 & 11 & 7 \\
3 Sociaal (wetensch.) opleiding & 38 & 37 & 46 \\
4 Bestuurskunde/rechten & 23 & 23 & 7 \\
5 Nat./Wis./Biologie/Statistiek & 3 & 2 & 0 \\
6 Informatie technologie & 0 & 1 & 0 \\
7 Techniek en Bouwkunde & 3 & 4 & 0 \\
8 Landbouwwetenschapplen & 1 & 1 & 0 \\
9 Levenswetenschappen & 1 & 2 & 0 \\
10 Dienstgerichte opleidingen & 0 & 0 & \\
\hline
\end{tabular}

De resultaten voor de studierichting in tabel 3 lijken $^{7}$ hypothese H2a te ondersteunen. Kamerleden van niet-Nederlandse herkomst hebben vaker dezelfde studieachtergrond als het standaard Kamerlid. De meeste Tweede Kamerleden hebben een achtergrond in de sociale wetenschappen (38\%) of bestuurskunde of rechten $(23 \%)$. In totaal volgt $71 \%(46 \%+25 \%)$ van de Kamerleden met een niet-Nederlandse achtergrond deze norm. Van de Kamerleden van Nederlandse herkomst volgt $60 \%(37 \%+23 \%)$ deze norm. Dat is een klein effect in de verwachte richting.

\subsubsection{Beroepsachtergrond}

Tabel 4 test hypothese H2b. Een arbeidsverleden in de publieke dan wel private sector is de norm. We zien - zoals verwacht - dat een (net) iets groter percentage Kamerleden met een niet-Nederlandse achtergrond inderdaad uit de publieke sector komt. Dit effect (b)lijkt echter verwaarloosbaar klein. Tevens werken Kamerleden met een niet-Nederlandse achtergrond maar zelden in de private sector. De resultaten ondersteunen $\mathrm{H} 2 \mathrm{~b}$ (het gelijkheidsmodel) daarmee 
niet. Dit gezegd hebbende, de beroepsachtergrond van Kamerleden met een nietNederlandse achtergrond blijkt lastig te classificeren (36\% versus 15\% niet eenduidig voor autochtone Nederlandse Kamerleden). Dat vertekent de interpretatie van de resultaten. Als we, post-hoc want ongepland, naar de relatieve marginale percentages kijken, dan blijkt van de succesvol geclassificeerde carrières $81 \%$ van de autochtone Nederlanders aan de norm te voldoen versus $85 \%$ van de Kamerleden met een andere etnische achtergrond, ${ }^{8}$ ondanks het lage aantal Kamerleden van niet-Nederlandse herkomst uit de private sector. Een tweede kanttekening in het voordeel van de hypothese is tevens dat bij de PvdA een publieke carrière wel de norm is: van alle 35 succesvol geclassificeerde PvdAKamerleden komen er $22(63 \%)$ uit de publieke sector. Bovendien zitten daar veel Kamerleden met een niet-Nederlandse achtergrond: 10 van de 28 (36\%) van de etnische minderheden in de populatie zijn PvdA-Kamerlid terwijl slechts $21 \%$ van de populatie PvdA-Kamerlid is. Al met al interpreteren wij deze resultaten als gebrek aan steun voor enige conclusie wat betreft hypothese $2 \mathrm{~b}$, positief dan wel negatief.

TABEL 4. Beroepsachtergrond (kolompercentages).

\begin{tabular}{cccc}
\hline \hline & Iedereen, N=217 & Nederlands, N=189 & Niet-Nederlands, N=28 \\
\hline Journalistiek & 5 & 6 & 0 \\
Leger & 2 & 2 & 0 \\
Private sector & 34 & 37 & 18 \\
Publieke sector & 33 & 32 & 36 \\
Vakbond & 9 & 8 & 11 \\
Niet eenduidig & 18 & 15 & 36 \\
\hline
\end{tabular}

\subsubsection{Politieke achtergrond}

TABEL 5. Politieke achtergrond (kolompercentages).

\begin{tabular}{cccc}
\hline \hline & Iedereen, N=217 & Nederlands, N=189 & Niet-Nederlands, N=28 \\
\hline Geen & 26 & 24 & 36 \\
Lokaal & 30 & 30 & 36 \\
Lokaal en Regionaal & 2 & 2 & 0 \\
Nationaal & 26 & 26 & 25 \\
Overig & 12 & 13 & 4 \\
Regionaal & 4 & 4 & 0 \\
\hline
\end{tabular}

Wat betreft $\mathrm{H} 2 \mathrm{c}$ (het derde type ervaring, de politieke achtergrond) ondersteunen de resultaten het idee van een gelijkheidsdynamiek echter wel weer. Tweede Kamerleden met een niet-Nederlandse achtergrond hebben inderdaad vaker een meer 
typisch type politieke carrière voor de Tweede Kamer. Tabel 5 laat zien dat het de norm is om vooral ervaring in de lokale of nationale politiek te hebben. Van alle Kamerleden met een niet-Nederlandse achtergrond voldoet $61 \%(36 \%+25 \%)$ aan deze norm, versus 56\% (30\% + 26\%) van de autochtone Nederlandse Kamerleden. Dat is een klein - en niet significant ${ }^{9}$ - verschil, maar het effect wijst wel de juiste kant op. Het is ook interessant dat 36\% van de Tweede Kamerleden met een andere etnische achtergrond geen politieke ervaring heeft. Dit percentage is relatief hoog.

$\mathrm{Al}$ met al interpreteren wij de resultaten wat betreft de standaardisering van het type ervaring als lichte steun voor het gelijkheidsmodel. Door het relatief kleine aantal Kamerleden met een niet-Nederlandse achtergrond moeten we hier echter wel een zekere slag om de arm te houden.

\subsection{Interactiemodellen: compensatie van normafwijking met meer ervaring?}

We hebben zojuist vastgesteld dat er weinig steun is voor het idee dat Kamerleden met een niet-Nederlandse achtergrond in het algemeen meer ervaring moeten hebben. We hebben voorts laten zien dat Kamerleden met een niet-Nederlandse herkomst - grosso modo - inderdaad vaker typische ervaring hebben. In het laatste deel van de analyses testen we hypothese 3, waarbij de nadruk ligt op het samenspel tussen deze twee factoren. Ondanks de gebrekkige steun voor hypothese 1 kan het immers nog steeds mogelijk zijn dat Kamerleden met atypische ervaring hiervoor moeten compenseren met meer ervaring (zelfs wanneer de groep over het algemeen gemiddeld beschouwd relatief onervaren is). De regressiemodellen in tabel 6 en tabel 7 onderzoeken deze dynamiek. De gepresenteerde modellen schatten steeds de hoeveelheid ervaring. Eerst de werkervaring (tabel 6) en dan de hoeveelheid politieke ervaring (tabel 7).

Als er sprake is van een samenspel tussen de hoeveelheid ervaring en het type ervaring dan zouden Kamerleden met een niet-Nederlandse achtergrond die niet het standaard ('normatieve') type ervaring hebben hiervoor moeten compenseren door meer ervaring te hebben.

De resultaten in tabel 6 en tabel 7 in ondersteunen dit idee (H3) echter niet. De verwachte interactie tussen het hebben van een niet-typische achtergrond en hoeveelheid is noch significant noch substantieel. Wij interpreteren dat als extra bewijs tegen de validiteit van een - naïef - compensatiemodel. Waar het de ondervertegenwoordiging van etnische minderheden in de Tweede Kamer betreft lijkt er meer aan de hand dan het ogenschijnlijk voor de hand liggende idee dat zij meer ervaring nodig hebben. 
TABEL 6. Regressiemodel, jaren prof. werkervaring bij binnenkomst in de Kamer.

\begin{tabular}{|c|c|c|}
\hline & \multicolumn{2}{|c|}{ Afhankelijke variabele } \\
\hline & \multicolumn{2}{|c|}{ Aantal jaren professionele werkervaring } \\
\hline & $(1)$ & $(2)$ \\
\hline Niet-Nederlands & $\begin{array}{l}-2.686 \\
(1.978)\end{array}$ & $\begin{array}{l}-1.855 \\
(2.678)\end{array}$ \\
\hline Geslacht:vrouw & & $\begin{array}{l}-0.461 \\
(1.536)\end{array}$ \\
\hline Niet de norm & & $\begin{array}{l}-1.630 \\
(4.019)\end{array}$ \\
\hline Niet-Nederlands*Niet norm & $\begin{array}{l}-1.735 \\
(1.364)\end{array}$ & $\begin{array}{l}-1.776 \\
(1.372)\end{array}$ \\
\hline Intercept & $\begin{array}{c}14.932^{* * * *} \\
(0.871)\end{array}$ & $\begin{array}{c}15.091^{* * * *} \\
(0.996)\end{array}$ \\
\hline $\mathrm{N}$ & 217 & 217 \\
\hline $\mathrm{R}^{2}$ & 0.017 & 0.019 \\
\hline Adjusted $\mathrm{R}^{2}$ & 0.008 & 0.0004 \\
\hline Residual Std. Error & $9.748(\mathrm{df}=214)$ & $9.784(\mathrm{df}=212)$ \\
\hline F Statistic & $1.850(\mathrm{df}=2 ; 214)$ & $1.020(\mathrm{df}=4 ; 212)$ \\
\hline $\begin{array}{l}\text { Noot 1: } \\
\text { Noot 2: }\end{array}$ & $\begin{array}{r}{ }^{*} \mathrm{p}<0.1 \\
\text { Standaa }\end{array}$ & $\begin{array}{l}{ }^{*} \mathrm{p}<0.05 ;{ }^{* * *} \mathrm{p}<0.01 \\
\text { fout tussen haakjes }\end{array}$ \\
\hline
\end{tabular}

TABEL 7. Regressiemodel, jaren politieke werkervaring bij binnenkomst in de Kamer.

\begin{tabular}{|c|c|c|}
\hline & \multicolumn{2}{|c|}{ Afhankelijke variabele } \\
\hline & \multicolumn{2}{|c|}{ Aantal jaren politieke werkervaring } \\
\hline & $(1)$ & $(2)$ \\
\hline Niet-Nederlands & $\begin{array}{c}-5.269^{* *} \\
(2.178)\end{array}$ & $\begin{array}{c}-5.558^{* *} \\
(2.785)\end{array}$ \\
\hline Geslacht:vrouw & $\begin{array}{c}-2.823^{*} \\
(1.503)\end{array}$ & $\begin{array}{l}-2.428 \\
(1.514)\end{array}$ \\
\hline Niet de norm & & $\begin{array}{c}-3.391^{* *} \\
(1.565)\end{array}$ \\
\hline Niet-Nederlands*Niet norm & & $\begin{array}{c}0.242 \\
(4.443)\end{array}$ \\
\hline Intercept & $\begin{array}{c}10.145^{* * *} \\
(0.959)\end{array}$ & $\begin{array}{c}11.488^{* * *} \\
(1.156)\end{array}$ \\
\hline Observations & 217 & 217 \\
\hline $\mathrm{R}^{2}$ & 0.045 & 0.068 \\
\hline Adjusted $\mathrm{R}^{2}$ & 0.036 & 0.050 \\
\hline Residual Std. Error & $10.735(\mathrm{df}=214)$ & $10.655(\mathrm{df}=212)$ \\
\hline F Statistic & $5.005^{* * *}(\mathrm{df}=2 ; 214)$ & $3.847^{* * *}(\mathrm{df}=4 ; 212)$ \\
\hline
\end{tabular}




\section{Conclusie en discussie}

Er is een toenemende aandacht voor diversiteit in politieke instituties en hoewel we weten dat etnische minderheden politiek ondervertegenwoordigd zijn in zowel Nederland als in andere landen, is er nog maar weinig bekend over de etnische minderheden die wel in de politiek aanwezig zijn. Zijn het buitenstaanders of zijn ze juist onderdeel van de politieke elite in Nederland? Moeten ze, omdat ze een andere etnische achtergrond hebben, compenseren met meer ervaring of zijn er weinig verschillen tussen Kamerleden met een Nederlandse en een niet-Nederlandse achtergrond? Om deze twee dynamieken - de compensatiedynamiek en de gelijkheidsdynamiek - te onderzoeken, vergeleken we de verschillen in de studie- en beroepskenmerken van Kamerleden van Nederlandse en niet-Nederlandse herkomst met unieke data van de parlementaire cohorten van 2010 en 2012.

Hoewel de resultaten variëren, lijkt er in Nederland meer bewijs te zijn voor de aanwezigheid van een gelijkheidsdynamiek dan voor een compensatiedynamiek. De resultaten ondermijnen het idee dat de politieke ondervertegenwoordiging van minderheden voortkomt uit een vertekend beeld bij selectiecommissies waarvoor etnische minderheden moeten compenseren. We zien dat, hoewel Kamerleden van nietNederlandse herkomst qua type ervaring veel op de bestaande politieke elite lijken, dat expliciet niet zo is wat betreft de duur van deze ervaring. Onze bevindingen suggereren dat etnische minderheden een atypische politieke carrière doorlopen waarin ze sneller dan autochtone Nederlandse politici in de Tweede Kamer terechtkomen. Dat zien we ook terug in het aandeel Kamerleden van niet-Nederlandse herkomst dat helemaal geen preparlementaire politieke ervaring heeft. Dat is een interessante bevinding die meer empirische aandacht verdient. Het suggereert immers dat politieke partijen niet-Nederlandse kandidaten minder uit de traditionele kanalen rekruteren en tevens dat er mogelijk actiever naar geschikte kandidaten van niet-Nederlandse herkomst wordt gezocht. Toekomstige studies zouden specifiek kunnen kijken naar de zoekstrategieën van politieke partijen voor de werving van etnische kandidaten. Op basis van onze resultaten verwachten wij dat de mogelijke uitkomst van een dergelijke studie zal zijn dat er in Nederland positieve discriminatie plaatsvindt, waarbij overeenkomsten in de studie- en beroepsachtergrond nog steeds belangrijk zijn maar waar kandidaten met een niet-Nederlandse achtergrond minder professionele en politieke ervaring hebben.

Een aantal belangrijke kanttekeningen is op zijn plaats. Zo is de periode van onderzoek (2010 en 2012) relatief kort. Met 28 Kamerleden die een niet-Nederlandse achtergrond hebben, is het lastig om met zekerheid uitspraken te doen op basis van de statistische bevindingen. Hoewel eerder beschrijvend onderzoek in andere landen zoals Frankrijk en het Verenigd Koninkrijk (Durose et al., 2012; Murray, 2016) ook laat zien dat de achtergrondkenmerken van politici met een andere etnische achtergrond grotendeels overeenkomen met die van autochtone politici ontbreekt 
het nog steeds aan een overkoepelend comparatief onderzoek. Alleen een onderzoek met afdoende onderscheidend vermogen om harde statistische uitspraken te kunnen doen kan dit soort vragen echt beantwoorden. Toekomstig onderzoek zal moeten uitwijzen of de conclusies waar onze resultaten naar wijzen ook overeind blijven wanneer er empirisch wordt getoetst met meer data die verschillende contexten en een langere tijdsperiode omvatten.

Het is bovendien ook denkbaar dat andere achtergrondkenmerken van Kamerleden met een etnische achtergrond kunnen verklaren waarom wij geen aanwijzingen voor een compensatiedynamiek vinden, zoals mediabekendheid of een groot netwerk in de eigen etnische groep. Nader onderzoek moet uitwijzen of andere individuele kenmerken kunnen verklaren waarom etnische minderheden minder professionele en politieke ervaring nodig lijken te hebben dan autochtone Nederlandse Kamerleden en/of welke partijstrategieën hier een rol in spelen.

Een derde kanttekening is dat wij de aanname maken dat de norm in de gehele Tweede Kamer van belang is. Het is echter ook mogelijk dat de typische profielen die van belang zijn voor politici per partij verschillen, bijvoorbeeld met betrekking tot beroepsachtergrond. De norm in de Tweede Kamer als geheel zal soms verschillen van de norm binnen politieke partijen. Het zou interessant zijn om, als er meer data beschikbaar zijn, theoretisch en empirisch te bestuderen of de norm op Kamerniveau dan wel op partijniveau het meest van belang is.

Een laatste kanttekening is dat we alleen een vergelijking hebben kunnen maken tussen Tweede Kamerleden met een Nederlandse en een niet-Nederlandse herkomst. Om daadwerkelijk selectiemechanismen en compensatie- en gelijkheidsdynamieken te onderzoeken zou het beter zijn om een vergelijking te maken tussen kandidaten met verschillende etnische achtergronden. Data over de studie- en beroepskenmerken van alle kandidaten op de kandidatenlijst zijn echter niet beschikbaar waardoor een dergelijke toetsing niet mogelijk is.

De resultaten van deze studie bevestigen opnieuw dat er een kloof bestaat tussen burgers en politici (Bovens \& Wille, 2010). Ook Kamerleden met een andere etnische achtergrond verschillen van de burgers met een Nederlandse dan wel nietNederlandse achtergrond in hun achtergrondkenmerken. Het blijft daarom cruciaal om meer inzicht te krijgen in het belang van descriptieve vertegenwoordiging.

\section{Noten}

1. Overigens blijkt uit eerder onderzoek dat Kamerleden met een andere etnische achtergrond ook relatief vaak vrouw zijn (Celis et al., 2014). De mate waarin etnische minderheden als een homogene groep beschouwd kunnen worden is terecht onderwerp van discussie. Verschillen in bijvoorbeeld etnische groep, geslacht en sociaaleconomi- 
sche status hebben mogelijk invloed op hun politieke vertegenwoordiging, participatie en status.

2. Het is mogelijk om door voorkeursstemmen een zetel te krijgen; dat is sinds 2002 slechts zeven keer gebeurd; Parlement \& Politiek, 2016).

3. Mügge (2016) deed een studie naar de werving en selectie van kandidaten met een andere etnische achtergrond in Nederland, daar ligt de nadruk echter op geslacht en etnische achtergrond.

4. Theoretisch gezien is het hebben van een andere etnische achtergrond het belangrijkste verschil. Bovendien kunnen niet alleen uiterlijke kenmerken ('zichtbare minderheden') een rol spelen, maar ook verwachtingen over de kennis van de taal of culturele/bestuurlijke kennis van kandidaten kunnen van invloed zijn op de keuzes van selectiecommissies.

5. Het gaat hier om opleidingen op het vlak van persoonlijke vaardigheden die zich op een breed scala aan onderwerpen richten en niet op specifieke onderwerpen of specialisaties.

6. De aanname hierbij is dat deze norm relatief stabiel is, oftewel, dat de meest voorkomende achtergrond in 2010-2016 niet sterk verschilt van de norm in de parlementen van voorgaande jaren en dat die niet aanzienlijk verschilt tussen partijen. Extra analyses (beschikbaar op verzoek) bevestigen deze twee aannames.

7. De geschatte kans voor een Kamerlid met een niet-Nederlandse achtergrond om aan de norm te voldoen is [54\% - 88\%] versus [52\% - 67\%] voor Kamerleden van Nederlandse herkomst. Model beschikbaar op verzoek.

8. $85 \%$ voor autochtone Nederlandse Kamerleden, $64 \%$ voor Kamerleden met een andere etnische achtergrond.

9. De geschatte kans voor een niet-Nederlands Kamerlid om aan de norm te voldoen is [ $43 \%-79 \%$ ] versus [ $47 \%-61 \%$ ] voor autochtone Nederlandse Kamerleden. Model beschikbaar op verzoek. 


\section{Bibliografie}

Arrow, K.J. (1971). Some Models of Racial Discrimination in the Labor Market. Santa Monica: The Rand Corporation.

Aydemir, A. \& Vliegenthart, R. (2016). 'Minority Representatives' in the Netherlands: supporting, silencing or suppressing? Parliamentary Affairs, 69(1), 73-92.

Bird, K. (2005). The political representation of visible minorities in electoral democracies: a comparison of France, Denmark, and Canada. Nationalism and Ethnic Politics, 11(4), 425-465.

Black, J.H. (2000). Entering the political elite in Canada: The case of minority women as parliamentary candidates and MPs. The Canadian Review of Sociology, 37(2), 143-166.

Black, J.H. \& Erickson, L. (2000). Similarity, compensation, or difference? Women Politics, 21(4), 1-38.

Bovens, M. \& Wille, A. (2010). The education gap in participation and its political consequences. Acta Politica, 45(4), 393-422.

Celis, K., Erzeel, S., Mügge, L., \& Damstra, A. (2014). Quotas and Intersectionality: Ethnicity and Gender in Candidate Selection. International Political Science Review 35(1), 41-54.

Centraal Bureau voor de Statistiek (CBS) (2016, 26 februari). Bevolking; generatie, geslacht, leeftijd en herkomstgroepering. http://statline.cbs.nl/StatWeb/ publication/?DM $=$ SLNL\&PA $=37325$.

Centraal Bureau voor de Statistiek (CBS) (2017, 10 juli). Bevolking; hoogstbehaald onderwijsniveau en onderwijsrichting. http://statline.cbs.nl/StatWeb/publication/ $? \mathrm{VW}=\mathrm{T} \& \mathrm{DM}=\mathrm{SLnl} \& \mathrm{PA}=82816 \mathrm{NED} \& \mathrm{LA}=\mathrm{nl}$.

Cotta, M. \& Best, H. (Eds.) (2007). Democratic representation in Europe: diversity, change, and convergence (pp. 1-26). Oxford: Oxford University Press.

Dancygier, R.M., Lindgren, K.O., Oskarsson, S., \& Vernby, K. (2015). Why are immigrants underrepresented in politics? Evidence from Sweden. American Political Science Review 109(04), 703-724.

Durose, C., Richardson, L., Combs, R., Eason, C., \& Gains, F. (2012). 'Acceptable Difference': Diversity, representation and pathways to UK politics. Parliamentary Affairs, 66(2), 1-22.

Ensel, R. (2003). Multiculturalisme in de politieke partij. Migrantenstudies 3, 156-172.

Fennema, M. \& Tillie, J. (1999). Political Participation and Political Trust in Amsterdam: Civic Communities and Ethnic Networks. Journal of Ethnic and Migration Studies 25, 703-726.

Fennema, M. (2003). Over De Kwaliteit Van Politieke Elites. Amsterdam: Amsterdam University Press.

Keane, M.P. \& Merlo, A. (2010). Money, Political Ambition, and the Career Decisions of Politicians. American Economic Journal: Microeconomics, 2(3), 186-215. 
Lucardie, P. \& Voerman, G. (2004). Portaal tot het Parlement. Kandidaatstelling binnen Politieke Partijen in acht Westerse landen. Den Haag/Groningen: Documentatiecentrum Nederlandse Politieke Partijen.

Michon, L. \& Vermeulen, F. (2013). Explaining Different Trajectories in Immigrant Political Integration: Moroccans and Turks in Amsterdam. West European Politics 36(3): 597-614.

Mügge, L.M. (2016). Intersectionality, Recruitment and Selection: Ethnic Minority Candidates in Dutch Parties. Parliamentary Affairs, 69(3), 512-530.

Murray, R. (2016). The political representation of ethnic minority women in France. Parliamentary Affairs, 69(3), 586-602.

Norris, P. \& Lovenduski, J. (1995). Political recruitment: Gender, race and class in the British Parliament. Cambridge: Cambridge University Press.

Parlement en Politiek (2016, 30 mei). Voorkeurstemmen. http://www.parlement.com/ id/vh8lnhrouwzc/voorkeurstemmen.

Phelps, E.S. (1972). The Statistical theory of Racism and Sexism. American Economic Review, 62(4), 659-661.

Phillips, A. (1995). The Politics of Presence: The Political Representation of Gender, Ethnicity, and Race. Oxford: Oxford University Press.

Pitkin, H. (1967). The Concept of Representation. Berkeley: University of California Press.

Rath, J. (1990). Political Participation of Ethnic Minorities in the Netherlands. International Migration Review, 17(3), 445-469.

Scarrow, S., Webb, P., \& Farrell, D.M. (2000). From Social Integration to Electoral Contestation: The Changing Distribution of Power within Political Parties. In: Dalton, R.J. \& Wattenberg, M.P. (ed.), Parties without Partisans: Political Change in Advanced Industrial Democracies. Oxford: Oxford University Press.

Sobolewska, M. (2013). Party Strategies and the Descriptive Representation of Ethnic Minorities: the 2010 British General Election. West European Politics, 36(3), 615-633.

Tillie, J. (1998). Explaining migrant voting behaviour in the Netherlands. Combining the electoral research and ethnic studies perspective. Revue europeenne des migrations internationales, 14(2), 71-95.

Turner-Zwinkels, T. (aanstaande). PolCa data: The Political Careers and Political Capital of Dutch MP'S (Version as per 24th of June 2017).

Turner-Zwinkels, T. \& Mills, M. (aanstaande). Pathways to Power: The Role of Political Capital in the Obtainment of Cabinet Positions.

van der Zwan, R., Lubbers, M. \& Eisinga, R. (aanstaande). The political representation of ethnic minorities in the Netherlands: Ethnic minority candidates and the role of party characteristics.

van Tubergen, F. (2006). Immigrant Integration: A Cross-National Study. New York: LFB Scholarly Publishing. 
Zschirnt, E. \& Didier, R. (2016). Ethnic discrimination in hiring decisions: a meta-analysis of correspondence tests 1990-2015. Journal of ethnic and migration studies, 42(7), 1115-1134.

\section{Bijlage 1: algemene beschrijvende statistiek}

TABEL 8. Samenvatting continue variabelen.

\begin{tabular}{lccccc}
\hline \hline Statistiek & $\mathrm{N}$ & Gemiddelde & St. Dev. & Min & Max \\
\hline Jaren prof. ervaring & 217 & 13.922 & 9.786 & 0.000 & 53.583 \\
Jaren politieke ervaring & 217 & 8.386 & 10.932 & 0.000 & 63.167 \\
Leeftijd bij binnenkomst & 217 & 40.562 & 8.521 & 20 & 62 \\
\hline
\end{tabular}

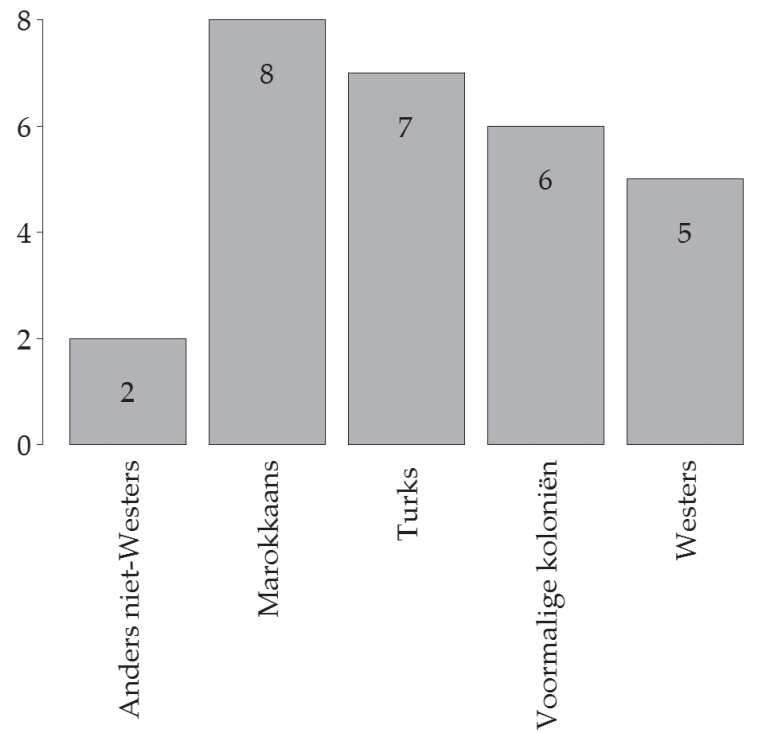

FIGUUR 3. Details Kamerleden met een niet-Nederlandse achtergrond in de dataset. 
DE ETNISCHE POLITIEKE ELITE VAN NEDERLAND


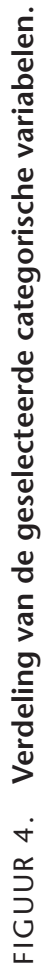

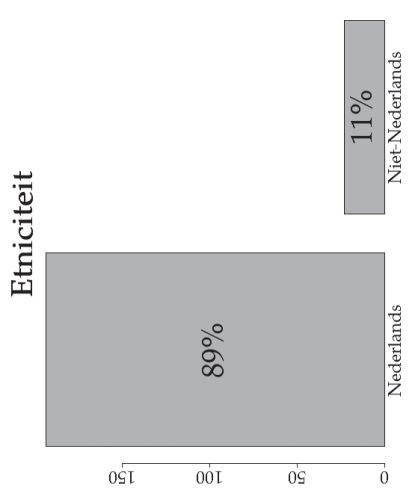

